\title{
Usage of Edible Mushrooms in Various Food Products
}

\author{
Özge Süfer ${ }^{*}$, Fuat Bozok ${ }^{2}$, Hande Demir ${ }^{1}$ \\ ${ }^{1}$ Food Engineering Department, Faculty of Engineering, Osmaniye Korkut Ata University, 80000, Osmaniye, Turkey \\ ${ }^{2}$ Biology Department, Faculty of Arts and Sciences, Osmaniye Korkut Ata University, 80000, Osmaniye, Turkey
}

\section{A R T I C L E I N F O}

\section{Article history:}

Received 20 November 2015

Accepted 10 February 2016

Available online, ISSN: $2148-127 \mathrm{X}$

Keywords:

Mushroom

Snack

Meatball

Agaricus bisporus

Pleurotus ostreatus

\begin{tabular}{l}
\hline CCorresponding Author: \\
\hline E-mail: ozgesufer@osmaniye.edu.tr
\end{tabular}

\begin{abstract}
A B S T R A C T
Use of edible mushrooms which are generally consumed in houses in dried form is based on mainly instant soup and sauce formulations. Recently, the cultivations of Agaricus bisporus and Pleurotus ostreatus species have become widespread. Utilization of these cultivated mushrooms in recipes would bring added value to related food products. For this purpose, A. bisporus and P. ostreatus species farmed in Osmaniye Korkut Ata University Mushroom House were dried and then pulverized. Firstly, a snack was prepared with A. bisporus powder. A. bisporus powder was substituted for wheat flour at the rates of $5 \%, 10 \%, 20 \%$ and $30 \%$ and thus the potential of food product which had relatively lower carbohydrate and fat level and higher fiber content was investigated. In the second part of the study, either 5\%,10\% of A. bisporus powder or 5\%,10\% of $P$, ostreatus powder were added into traditional Turkish meatball (beef mince, salt) which was cooked in conventional oven, so meat flavor could be replaced by herbal flavor coming from mushroom. This property mat obey the purpose that, the created new product will be consumed fondly especially by children. Sensory and physical (colour and texture) analysis were performed in both snack and meatball samples and the results were evaluated statistically.
\end{abstract}

Türk Tarım - Gıda Bilim ve Teknoloji Dergisi, 4(3): 144-149, 2016

\section{Yenebilir Mantarların Çeşitli Gıda Ürünlerinde Kullanımı}

\section{A K A L E B İ L G İ S İ}

Geliş 20 Kasım 2015

Kabul 10 Şubat 2016

Çevrimiçi baskı, ISSN: 2148-127X

Anahtar Kelimeler:

Mantar

Atıştırmalık

Köfte

Agaricus bisporus

Pleurotus ostreatus

*Sorumlu Yazar:

E-mail: ozgesufer@osmaniye.edu.tr

\section{Ö Z E T}

Kurutulmuş şekilde tüketilebilen yenebilir mantarların kullanımı ağırlıklı olarak hazır çorba ve sos formülasyonları şeklindedir. Son zamanlarda yetiştiriciliği yaygınlaşan Agaricus bisporus ve Pleurotus ostreatus mantarlarının çeşitli gıda formülasyonlarında kullanılması ile bu mantar türlerine katma değer kazandırılması gerektiği düşünülmektedir. $\mathrm{Bu}$ amaçla, Osmaniye Korkut Ata Üniversitesi mantarhanesinde yetiştirilen $A$. bisporus ve $P$. ostreatus mantarları uygun koşullarda kurutularak toz haline getirilmiştir. İlk olarak $A$. bisporus tozu ile atıştırmalık hazırlanmıştır. Buğday unu ile $\% 5$ - \%10 - \%20 ve \%30 oranlarında yer değişimi yapılmış ve bu şekilde karbonhidrat ve yağ değerleri göreceli olarak daha düşük ve lif oranı daha yüksek bir ürünün potansiyeli araştırılmıştır. Çalışmanın ikinci bölümünde ise geleneksel firın köfte (dana kıyması, tuz) tarifine $\% 5$ ve $\% 10$ oranlarında A. bisporus ve $P$. ostreatus mantar tozları eklenmiş ve bu şekilde köftedeki etsi aromanın mantardan gelen aroma ile yer değiştirmesi böylece köftenin daha kolay tüketilebilmesi amaçlanmıştır. Hem atıştırmalıklar hem de köfte örnekleri fiziksel (tekstür ve renk) ve duyusal olarak analiz edilmiş olup, duyusal analiz sonuçları istatistiksel olarak değerlendirilmiştir. 


\section{Introduction}

Mushrooms are known as healthy foods and dietary nutrients in all over the world, because they include rich amounts of vegetable proteins, chitin, essential amino acids, vitamins, minerals and low fat and calories (Manzi et al., 1999; Pedneault et al., 2008). On dry basis, an edible mushroom has $56.8 \%$ carbohydrate, $25.0 \%$ protein, $5.7 \%$ fat and $12.5 \%$ ash contents (Demirbaş, 2002; Mendil et al., 2004). However, mushrooms are considered as not only a food source but also having medicinal properties because of bioactive compounds (Chiu et al., 2000; Chang and Miles, 2004). Also, edible mushrooms could be useful for many diseases such as hypertension, cancer and cholesterol (Bobek and Galbavy, 1999; Borchers et al., 1999).

For many years, cereal products have been existing in human's life and they are the most preferred food materials in the world (Kramer, 1996). Because of this reason, baking industry has grown rapidly and bakery products such as bread, croissant, snack etc. have taken huge part in international food market. But obesity, cardiovascular diseases, diabetes and some types of cancers are directly related to dietary habits $(\mathrm{Hu}, 2002)$. In order to reduce the risks, consumers tend to try new but healthier food products. Hence, baking industry should follow last and healthy trends (Byrne, 2000; Kohn, 2000; Kotsianis et al., 2002). This may be succeeded through processing or reformulation of food products such as nonthermal operations or functional foods (Reisch and Gwozdz, 2011; Kaur and Das, 2011; Aschemann-Witzel, 2015). Researchers have focused on substitution of various flour types for wheat flour to satisfy demands for healthier foods recently (Coelho and Salas-Mellado, 2015).

Meat and meat products include significant amount of proteins, vitamins and minerals and the consumption of these foods has been growing in developing countries (FAO, 2013; Ledesma et al., 2016). Especially red meat contains high amount of iron, zinc, selenium, potassium and a range of B-vitamins including niacin, riboflavin, thiamine and vitamin B12 (Wyness et al., 2011). Because of saturated fatty acids, doctors and researchers had suggested to reduce red meat in daily diet for several years. But studies conducted in Europe and North America showed that, there were no correlation between red meat consumption and various diseases such as cancer and cardiovascular disorders (Siri-Tarino et al., 2010; Kappeler et al., 2013; Rohrmann et al., 2013; Chowdhury et al., 2014). Recent studies also pointed out that unprocessed and processed meat products (salami, sausages etc.) should be distinguished (Binnie et al., 2014). Instead of consuming synthetic food additives or chemicals from processed meats, unprocessed meats like mince could be seasoned with natural compounds.

In previous studies, some fungi species were investigated by different researchers as food additives (Chockchaisawasdee et al., 2010; Wakchaure et al., 2010; Okafor et al., 2012; Aishah and Wan Rosli, 2013; Hafel et al., 2014). The present study is an important indicator on availability as a food additive in products such as meatball and snacks from dried A. bisporus and $P$. ostreatus and focuses colour, textural and sensorial properties of mentioned novel foods.

\section{Materials and Methods}

\section{Production, Harvesting and Drying of Mushrooms}

Agaricus bisporus ve Pleurotus ostreatus were produced by using composts in Mushroom House of Osmaniye Korkut Ata University. Air conditioning, ventilation and humidification systems are available in mushroom house. Firstly, rooms were disinfected by using $1 \%$ formaldehyde during 7 days before setting composts. Composts were placed to these rooms adjusted to the environmental conditions for mycelial growth. $P$. ostreatus mushrooms were cultivated at the lighting conditions after mycelial growth, while A. bisporus mushrooms were cultivated in a dark room. Mushrooms were harvested before opening their caps. Harvested mushrooms were dried by dehydrator (Kangye, KYS 329) during 1 day at $60^{\circ} \mathrm{C}$. And then, dried mushroom samples were powdered by commercial blender (Waring, Germany) and were stored in glass jars at $+4^{\circ} \mathrm{C}$ until analysis.

\section{Preparation of Snacks}

Recipe was modified from Anonymous, 2015a. Control sample includes $77 \%$ wheat flour, $19 \%$ margarine, $3.8 \%$ yoghurt and $0.2 \%$ salt. A. bisporus powder was the only type used in production of snacks since it is cheaper and more available than $P$. ostreatus and snacks are generally composed of more affordable components in terms of other food materials. A. bisporus mushroom powder was substituted for wheat flour at the rates of $5 \%, 10 \%, 20 \%$ and $30 \%$. Doughs were made by manually and cooked in a house-type conventional oven (Arçelik, MF 44) at $180^{\circ} \mathrm{C}$ for 10 minutes. A snack was produced from approximately 15 grams of dough.

\section{Preparation of Meatballs}

A meatball which had no mushroom powder (control) contains only beef mince and salt. A. bisporus or $P$. ostreatus powders were used in production of meatballs. $5 \%$ or $10 \%$ of mushroom powders were added into meatballs. Preparation was made by manually and cooked in a commercial-type oven (Öztiryakiler, $10 \mathrm{GN} 2 / 1$ ) at $150^{\circ} \mathrm{C}$ for 150 minutes. A raw product had 30 grams of weight.

\section{Colour Analysis}

Minolta Chroma meter CR 400 was used for determining colours of samples. Total colour differences $(\Delta \mathrm{E})$ between products were evaluated by means of $\mathrm{L}$ (brightness), a (redness-greeness) and b (bluenessyellowness) values after cooking. Total colour difference could be expressed as follows;

$$
\Delta \mathrm{E}=\sqrt{\left(\mathrm{L}-\mathrm{L}_{\mathrm{ref}}\right)^{2}+\left(\mathrm{a}-\mathrm{a}_{\mathrm{ref}}\right)^{2}+\left(\mathrm{b}-\mathrm{b}_{\mathrm{ref}}\right)^{2}}
$$


Reference values were belonged to standard white plates of chroma meter. Colour of every sample was read two times from both top and bottom. Average L, a and b values were used for evaluation (Hunt and Kropf, 1987).

\section{Texture Analysis}

In order to perform an instrumental texture evaluation of both snack and meatball samples, Brookfield Texture Analyzer (CT3, Load cell: $4500 \mathrm{~g}$ ) was used. Texture profile analysis (TPA) performed two compression cycles and was applied to all samples by using penetration probe moving at a speed of $1 \mathrm{~mm} / \mathrm{s}$. Pre-test speed and post-test speed were $1 \mathrm{~mm} / \mathrm{s}$ and $2 \mathrm{~mm} / \mathrm{s}$ respectively (Raymundo et. al., 2014). Hardness was expressed as Newton (N). This parameter can be defined as the resistance of solid material when a pressure force is applied (Anonymous, 2015b).

\section{Sensory Analysis}

Thirty panelists for snack and twenty two panelists for meatball drawn from Osmaniye Korkut Ata University, Engineering and Arts and Science Faculties who were familiar with mushroom and non-smoker participated in sensory evaluation and tests were carried out within 1-2 hour after baking. Five types of snack (contained \%0, 5\%, $10 \%, 20 \%$ and $30 \%$ A. bisporus powder) and five types of meatball (included \%0 mushroom powder, 5\%, 10\% A. bisporus powder and 5\%,10\% P. ostreatus powder) were served to people. Both snack and meatball samples were named with 3 digits number. Panelists scored each sample using a 5-point Hedonic scale where 1=very bad and $5=$ very good. For the sensory assessment of snack; colour, taste, texture and overall acceptability and for meatball; colour, taste, chewiness and overall acceptability were questioned. Both food types (bakery and meat product) were compared in themselves. The results were analysed by SPSS Version 18.0 using oneway ANOVA while the means were separated with the help of Duncan test at $5 \%$ confidence level.

\section{Results and Discussion}

\section{Colour Analysis}

$\Delta \mathrm{E}$ values of snacks and meatballs are given in Figure 1 and 2, respectively. For snack samples, colour levels of products which contained $5 \%$ and $10 \%$ A. bisporus powder were considerably close to control. Total colour differences of $20 \%$ and $30 \%$ were slightly different than product that had no A. bisporus powder. The reason might be enzymatic and/or non-enzymatic reaction (Maillard) (Ulziijargal, 2009; Chen, 2009) and oxidation of phenolics (Ulziijargal et. al., 2013) taking place on the mushroom powder due to the applied heat treatment. In their research, Eissa et. al., (2007) showed that increased amount of mushroom flours in Egyptian balady bread and biscuits enhanced the values of $L$, $a$ and $b$. On the other hand, for meatballs, there were no significant differences between samples involved either A. bisporus or $P$. ostreatus powder in terms of colour. Because the main component that creates colour in meat and meat products is proteins and proteins may probably more dominant than mushroom powders. Similiarly, Rosli et. al., (2011) reported that addition of Pleurotus sajor-caju mushroom up to $50 \%$ to the formulation of chicken patties was not influenced redness (a) values of samples.

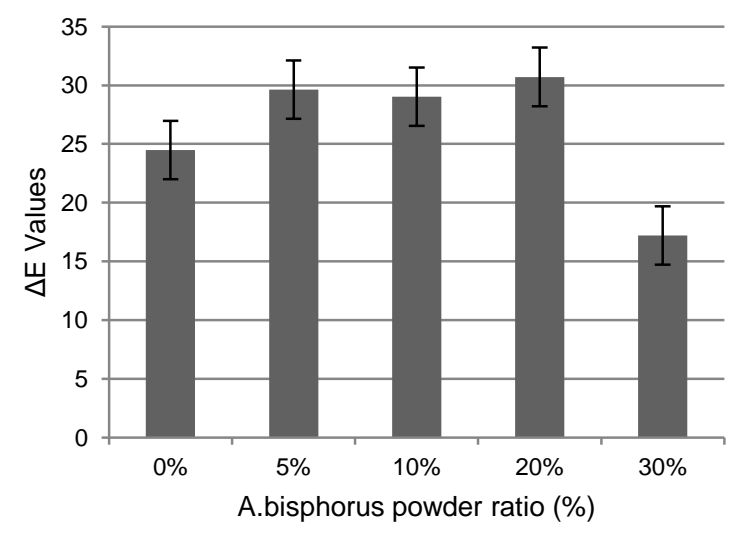

Figure 1 Total colour differences of snack samples with various mushroom powder ratios

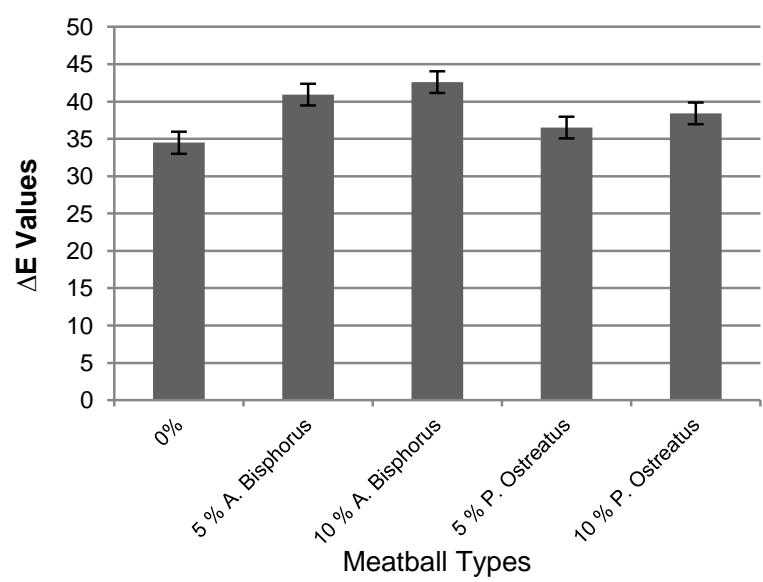

Figure $2 \Delta \mathrm{E}$ values versus meatball types

\section{Texture Analysis}

Any kind of mushroom powder addition into snack and meatball formulation enhanced the hardness value. Figure 3 and 4 shows the hardness levels of products versus percentage of mushroom powder. There was not any direct proportion between $A$. bisporus powder content and textural properties in snacks. Minimum hardness force belonged to sample comprised $10 \%$ A. bisporus. This may be due to nonuniform mixing of components while preparing dough. The texture of bread supplemented with $5 \%$ mushroom powder was significantly different than control bread, bread with $10 \%$ mushroom powder and $15 \%$ mushroom powder in Mahamud et. al.'s study (2012). Similar results were also found by Ulziijargal et. al. (2013). The mushroom mycelia addition into bread samples did not display a consistent trend. They attributed this situation to moisture loss during storage. Besides that, the concentration of $A$. 
bisporus powder has a positive effect on hardness in meatball samples. Needed force increased in parallel to the amount of $A$. bisporus powder. However, $P$. ostreatus powder behaved in an opposite way. Increment in the amount of $P$. ostreatus powder caused decrease in hardness of meatballs. The rehydration capacity and fat retention of $P$. ostreatus are relatively higher than the other, thus the differences may result from this situation (Aleson-Carbonella et al., 2005). Several researchers also claimed that some ingredients had a softening effect on meat structure and texture (Comer and Dempster, 1981; Tsai et al., 1998; Rosli et. al., 2011).

\section{Sensory Analysis}

According to the statistical analysis results of sensory tests of snacks (Table 1), the most favourite sample with respect to colour, taste and overall acceptability was the product which had $5 \%$ A. bisporus, after control. The lowest taste score pertained to $30 \%$ A. bisporus snack. The panelists indicated that this percentage gave themselves very intense aroma. Okafor et. al., (2012) produced breads containing up to $25 \%$ mushroom powder and indicated that the most preferable one was bread included 5\% mushroom power after $0 \%$. Also they showed that when mushroom powder concentration rose,

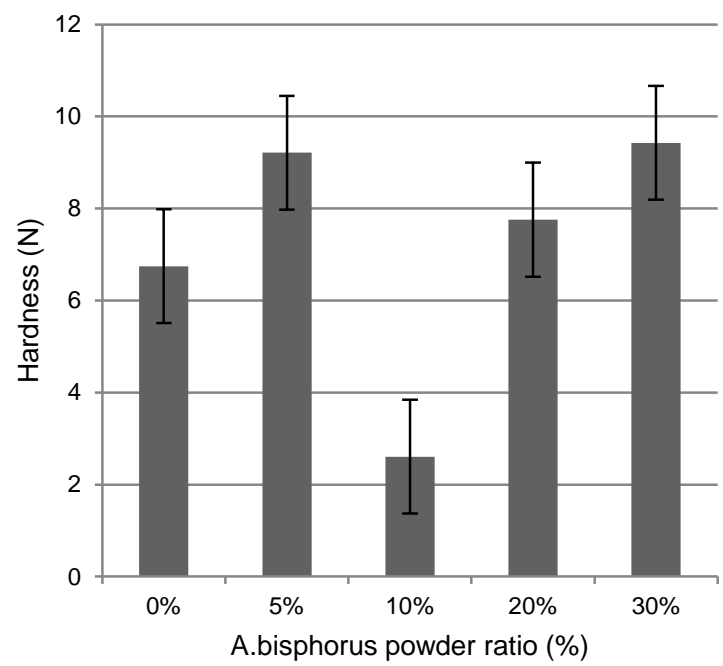

Figure 3 Hardness values of snacks sensory scores decreased. Our results gave similarities with Okafor et. al.'s (2012) findings. In the framework of texture, panelists categorized samples into two groups. There was not any significant difference between control sample and 5\% A. bisporus and also between 10\%, 20\% and $30 \% A$. bisporus $(\mathrm{P}<0.05)$. Meatball contained $5 \% P$. ostreatus was the best-liked one other than the control and $10 \%$ A. bisporus was the least (Table 2). Similiary, in a study of pork patties which contained mushroom powder stated that increased amount of shiitake (Lentinus edodes $P$.) mushroom powder in patties with phosphate decreased overall acceptability of U.S. consumers. Although, samples without phosphate enhanced the acceptability level of U.S. people. This could be originated from increasing effect of tripolyphosphate in juiciness (Chun, et. al., 2005). Colour and taste differences between control sample and 5\% P. ostreatus meatball were found unimportant statistically, but the difference among other samples was seen significant $(\mathrm{P}<0.05)$. So, using of $P$. ostreatus powder at the rate of $5 \%$ would be acceptable. This result could make the consumption of meatball possible especially by children. Because, meat flavor might probably be replaced with herbal flavor coming from mushroom.

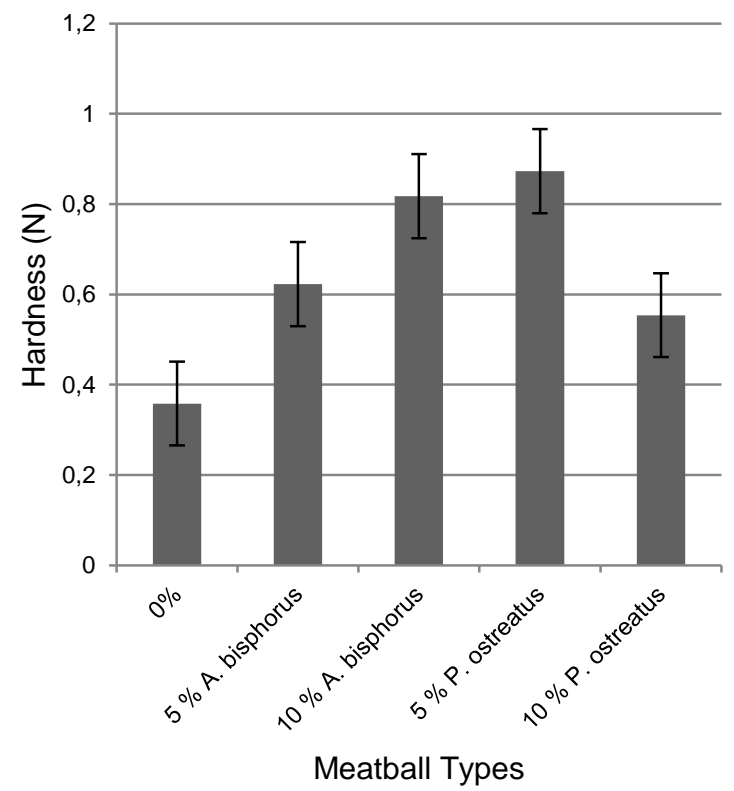

Figure 4 Hardness levels versus meatball types

Table 1 Sensory scores of A.bisphorus snacks $(\mathrm{N}=30)$

\begin{tabular}{l|ccccc}
\hline \multirow{2}{*}{ Sensory Attributes } & \multicolumn{4}{|c}{ A.bisphorus powder concentration } \\
\cline { 2 - 6 } & $0 \%$ & $5 \%$ & $10 \%$ & $20 \%$ & $30 \%$ \\
\hline Color & $4.100 \pm 0.884^{\mathrm{a}}$ & $3.166 \pm 0.746^{\mathrm{b}}$ & $3.133 \pm 0.973^{\mathrm{b}}$ & $2.200 \pm 0.664^{\mathrm{c}}$ & $1.500 \pm 0.682^{\mathrm{d}}$ \\
Taste & $3.866 \pm 0.937^{\mathrm{a}}$ & $3.166 \pm 0.746^{\mathrm{b}}$ & $2.766 \pm 1.006^{\mathrm{b}}$ & $2.200 \pm 0.847^{\mathrm{c}}$ & $1.533 \pm 0.681^{\mathrm{d}}$ \\
Texture & $3.933 \pm 0.868^{\mathrm{a}}$ & $3.533 \pm 0.899^{\mathrm{a}}$ & $2.733 \pm 1.230^{\mathrm{b}}$ & $2.600 \pm 1.037^{\mathrm{b}}$ & $2.233 \pm 1.194^{\mathrm{b}}$ \\
Overall Acceptability & $3.967 \pm 0.890^{\mathrm{a}}$ & $3.266 \pm 0.691^{\mathrm{b}}$ & $2.766 \pm 0.971^{\mathrm{c}}$ & $2.166 \pm 0.746^{\mathrm{d}}$ & $1.600 \pm 0.674^{\mathrm{e}}$ \\
\hline
\end{tabular}

Mean values within the same row expressing different letters differ significantly $(\mathrm{P}<0.05)$; (Score $1=$ very bad and score $5=$ very good) 
Table 2. Sensory scores of mushroom meatballs $(\mathrm{N}=21)$

\begin{tabular}{l|ccccc}
\hline \multirow{2}{*}{ Sensory Attributes } & \multicolumn{4}{|c}{ Mushroom Powder Type - Concentration } \\
\cline { 2 - 6 } & WMP $^{1}$ & \multicolumn{2}{|c}{ A.bisphorus } & \multicolumn{2}{c}{ P.ostreatus } \\
\cline { 2 - 6 } & $0 \%$ & $5 \%$ & $10 \%$ & $5 \%$ & $10 \%$ \\
\hline Color & $3.952 \pm 1.071^{\mathrm{a}}$ & $3.238 \pm 0.944^{\mathrm{b}}$ & $1.666 \pm 0.730^{\mathrm{d}}$ & $4.142 \pm 0.853^{\mathrm{a}}$ & $2.238 \pm 0.995^{\mathrm{c}}$ \\
Taste & $3.476 \pm 1.364^{\mathrm{a}}$ & $2.381 \pm 1.203^{\mathrm{b}}$ & $2.762 \pm 1.300^{\mathrm{ab}}$ & $2.905 \pm 0.889^{\mathrm{ab}}$ & $2.857 \pm 1.108^{\mathrm{ab}}$ \\
Chewiness & $3.952 \pm 0.921^{\mathrm{a}}$ & $3.095 \pm 0.889^{\mathrm{bc}}$ & $2.619 \pm 1.071^{\mathrm{c}}$ & $3.476 \pm 0.872^{\mathrm{ab}}$ & $3.190 \pm 1.123^{\mathrm{bc}}$ \\
Overall Acceptability & $3.476 \pm 1.364^{\mathrm{a}}$ & $2.714 \pm 0.956^{\mathrm{bc}}$ & $2.428 \pm 0.870^{\mathrm{c}}$ & $3.381 \pm 1.071^{\mathrm{ab}}$ & $2.809 \pm 0.981^{\mathrm{abc}}$ \\
\hline
\end{tabular}

1WMP: Without mushroom powder; Mean values within the same row expressing different letters differ significantly $(\mathrm{P}<0.05)$; $($ Score $1=$ very bad and score 5 = very good)

\section{Conclusion}

The results of snack with 5\% A. bisporus powder and meatballs with $5 \%$ P. ostreatus were promising for the production of aromatic and novel foods. But it is believed that the cooking parameters should be optimized and / or especially meat formulations is ought to be remodified in order to eliminate the undesirable colour or taste. This study is also believed to add value to two of the most produced mushroom species of Turkey.

\section{References}

Aishah MS, Wan Rosli WI. 2013. The effect of addition of oyster mushroom (Pleurotus sajor-caju) on nutrient composition and sensory acceptation of selected wheat- and rice-based products. International Food Research Journal, 20 (1): 183-188.

Aleson-Carbonella, L, Fernández-López, J, Pérez- Alvarez JA, Kuri V. 2005. Characteristics of beef burger as influenced by various types of lemon albedo. Innovative Food Science and Emerging Technologies 6: 247-255.

Anonymous. 2015a. Susaml1 Galeta. http://www.hamaratabla.com/ makale/2486,susamli-galeta.htm. Accessed: September, 2015.

Anonymous. 2015b. Hardness. https://en.wikipedia.org/wiki/ Hardness. Accessed: October, 2015.

Aschemann-Witzel J. 2015. Consumer perception and trends about health and sustainability: trade-offs and synergies of two pivotal issues. Current Opinion in Food Science, 3: 6-10.

Binnie MA, Barlow K, Johnson V, Harrison C. 2014. Red meats: Time for a paradigm shift in dietary advice. Meat Science, 98 (3): 445-451

Bobek P, Galbavy S. 1999. Hypocholesterolemic and antiatherogenic effect of oyster mushroom (Pleurotus ostreatus) in rabbits. Nahrung, 43: 339-342.

Borchers AT, Stern JS, Hackman RM, Keen CL, Gershwin ME. 1999. Mushrooms, Tumors, and Immunity. Proceedings of the Society for Experimental Biology and Medicine, 221: 281-293.

Byrne M. 2000. Barilla: investing for the future. Food Engineering and Ingredients, 25: 18-23.

Chang ST, Miles PG. 2004. The nutritional attributes of edible mushrooms. In: Chang ST, Miles PG (eds), Mushrooms: cultivation, nutritional value, medicinal effect, and environmental impact, $2^{\text {nd }}$ edn. CRC Press, Boca Raton, pp. 27 37.

Chen CP. 2009. Quality evaluation of Antrodia mycelium bread and Phellinus mycelium bread. Master's Thesis. National Chung Hsing University, Taichung, Taiwan.

Chiu SW, Law SC, Ching ML, Cheung KW, Chen MJ. 2000. Themes for mushroom exploitation in the 21 st century: sustainability, waste management, and conservation. Journal of General and Applied Microbiology 46: 269-282.

Chockchaisawasdee S, Namjaidee S, Pochana S, Stathopoulos CE. 2010. Development of fermented oyster-mushroom sausage. Asian Journal of Food and Agro-Industry, 3(1): 35-43.
Chowdhury R, Warnakula S, Kunutsor S, Crowe F, Ward HA, Johnson L. 2014. Association of dietary, circulating, and supplement fatty acids with coronary risk: A systematic review and meta-analysis. Annals of Internal Medicine, 160: 398-406.

Chun S, Chambers E, Chambers D. 2005. Perception of pork patties with shiitake (Lentinus edode P.) mushroom powder and sodium tripolyphosphate as measured by Korean and United States consumers. Journal of Sensory Studies, 20(2): 156-166.

Coelho MS, Salas-Mellado, MM. 2015. Effects of substituting chia (Salvia hispanica L.) flour or seeds for wheat flour on the quality of the bread. LWT - Food Science and Technology, 60: 729-736.

Comer FW, Dempster S. 1981. Functionality of fillers and meat ingredients in comminuted meat products. Canadian Institute of Food Science and Technology Journal, 14: 295-303.

Demirbaş A. 2002. Metal ion uptake by mushrooms from natural and artificially enriched soils. Food Chemistry, 78: 89-93

Eissa H, Hussein A, Mostafa B. 2007. Rheological properties and quality evaluation on Egyptian balady bread and biscuits supplemented with flours of ungerminated and germinated legume seeds. Polish Journal of Food and Nutrition Sciences, 57 (4): 487-496.

FAO. 2013. Meat \& meat products. Meat consumption. Food and Agriculture Organization of United Nations. Agriculture and Consumer Protection Department (Cited 2013 March 1). Retrieved April 28, 2014 from http://www.fao.org/ag/ againfo/themes/en/meat/background.html. Accessed: November, 2015.

Hafeel RF, Pubudangani I, Wijeratne V, Sumanawathi AP. 2014. Sensory and nutritional attributes of sausages developed with sprouted low amylose rice varieties. Annals of Sri Lanka Department of Agriculture, 16: 205-214.

Hu FB. 2002. Dietary pattern analysis: a new direction in nutritional epidemiology. Curr Opin Lipidol., 13(1): 3-9.

Hunt MC, Kropf DH. 1987. Eds. Color and appearance, Van Nostrand, New York. pp. 13-18.

Kappeler R, Eichholzer M, Rohrmann S. 2013. Meat consumption and diet quality and mortality in NHANES III. European Journal of Clinical Nutrition, 67: 598-606.

Kaur S. Das M. 2011. Functional foods: an overview. Food Sci Biotechnol., 20: 861-875.

Kohn S. 2000. An update of the US baking industry. Cereal Foods World, 45: 94-97.

Kotsianis IS, Giannou V, Tzia C. 2002. Production and packaging of bakery products using MAP technology. Trends in Food Science and Technology, 13 (9-10): 319-324.

Kramer A. 1996. Parameters of quality. Food Technology, 20: $1147-1148$.

Ledesma E, Laca A, Rendueles M, Díaz M. 2016. Texture, colour and optical characteristics of a meat product depending on smoking time and casing type. LWT - Food Science and Technology, 65: 164-172.

Mahamud MM, Shirshir MRI, Hasan MR. 2012. Fortification of wheat bread using mushroom powder. Bangladesh Research Publications Journal, 7 (1): 60-68. 
Manzi P, Gambelli L, Marconi S, Vivanti V, Pizzoferrato L. 1999. Nutrients in edible mushrooms: an inter-species comparative study. Food Chemistry, 65: 477-482.

Mendil D, Uluözlü OD, Hasdemir E, Cağlar A. 2004. Determination of trace elements on some wild edible mushroom samples from Kastamonu, Turkey. Food Chemistry, 88: 281-285.

Okafor JNC, Okafor GI, Ozumba AU, Elemo GN. 2012. Quality characteristics of bread made from wheat and Nigerian oyster mushroom (Pleurotus plumonarius) powder, Pakistan Journal of Nutrition, 11(1): 5-10.

Pedneault K, Angers P, Gosselin A, Tweddell RJ. 2008. Fatty acid profiles of polar and neutral lipids of ten species of higher basidiomycetes indigenous to eastern Canada. Mycological Research 112: 1428-1434.

Raymundo A, Fradinho P, Nunes MC. 2014. Effect of Psyllium fibre content on the textural and rheological characteristics of biscuit and biscuit dough. Bioactive Carbohydrates and Dietary Fibre, 3 (2): 96-105.

Reisch LA, Gwozdz W, 2011. Chubby cheeks and climate change: childhood obesity as a sustainable development issue. Int J Consum Stud., 35: 3-9.

Rohrmann S, Overvad K, Bueno-de-Mesquita HB, Jakobsen MU, Egeberg R, Tjønneland A. 2013. Meat consumption and mortality - Results from the European prospective investigation into cancer and nutrition. BMC Medicine, 11: 63.
Wan Rosli W, Solihah M, Aishah M, Nik Fakurundin N, Mohsin S. 2011. Colour, texture properties, cooking characteristics and fibre content of chicken patty added with oyster mushroom (Pleurotus sajor-caju). International Food Research Journal, 18: 621-627.

Siri-Tarino PW, Sun Q, Hu FB, Krauss RM. 2010. Meta-analysis of prospective cohort studies evaluating the association of saturated fatwith cardiovascular disease. American Journal of Clinical Nutrition, 91: 535-546.

Tsai SJ, Unklesbay N, Unklesbay K, Clarke A. 1998. Textural properties of restructured beef products with five binders at four isothermal temperatures. Journal of Food Quality 21: 397-410.

Ulziijargal E. 2009. Quality evaluation of Agaricus mycelium bread and Hericium mycelium bread. Master's Thesis. National Chung Hsing University, Taichung, Taiwan.

Ulziijargal E, Yang JH, Lin LY, Chen CP, Mau JL. 2013. Quality of bread supplemented with mushroom mycelia. Food Chemistry, 138(1): 70-76.

Wakchaure GC, Shirur M, Manikandan K, Rana L. 2010. Development and evaluation of oyster mushroom value added products. Mushroom Research, 19 (1): 40-44.

Wyness L, Weichselbaum E, O'Connor A, Williams EB, Benelam B, Riley H, Stanner S. 2011. Red meat in the diet: An update. British Nutrition Foundation Nutrition Bulletin, 36: 34-77. 